\title{
Pengaruh Pendekatan Saintifik terhadap Hasil Belajar Siswa Melalui Pembelajaran Tematik-Integratif pada Mata Pelajaran Matematika di Madrasah Ibtidaiyahnegeri Belitang II OKU Timur
}

\author{
WELLI MEINARNI ${ }^{1}$,SRI ENGGAR KENCANA DEWI ${ }^{2}$ \\ STKIP NURUL HUDA OKU TIMUR \\ E-mail: welli@stkipnurulhuda.co.id
}

\begin{abstract}
Abstrak
Penelitian ini bertujuan untuk mendeskripsikan pengaruh pendekatan saintifik terhadap hasil belajar siswa melalui pembelajaran tematik-integratif pada mata pelajaran matematika kelas IV di MIN Tanjung Kemuning. Penelitian ini menggunakan pendekatan kuantitatif dengan metode quasi-eksperimen tepatnya desain nonequivalent groups pretestposttest. Variabel terikat dalam penelitian ini adalah hasil belajar siswa dan variabel bebasnya adalah pembelajaran tematik-integratif dengan pendekatan saintifik. Populasi penelitian ini adalah seluruh siswa dan siswi kelas IV di MIN Tanjung Kemuning dengan jumlah 45 orang. Sampel dalam Penelitian ini diambil menggunakan Sampling jenuh, sampling jenuh adalah mengambil seluruh anggota populasi sebagai sampel. Teknik pengumpulan data yang digunakan dalam penelitian ini adalah teknik tes dan observasi. Data yang telah diperoleh dari tes hasil belajar siswa dianalisis dengan menggunakan Independent Sample $t$-Test dengan bantuan software SPSS pada taraf signifikansi $5 \%(\alpha=0,05)$.Penelitian ini menunjukkan bahwa pembelajaran tematik-integratif dengan pendekatan saintifik berpengaruh positif terhadap hasil belajar siswa dibandingkan dengan pembelajaran konvensional.
\end{abstract}

\section{Kata kunci: Pembelajaran Tematik-Integratif dengan Pendekatan Saintifik, Hasil Belajar.}

\section{PENDAHULUAN}

Pendidikan mempunyai peranan penting dalam perkembangan suatu bangsa, karena pendidikan merupakan tempat untuk mengembangkan kualitas sumber daya manusia. Hal tersebut sudah terbukti bahwa berbagai bangsa di dunia yang menempatkan sektor pendidikan sebagai garda terdepan dalam prioritas pembangunan bangsanya. Misalnya negara Jepang yang hancur akibat perang dunia II tragedi bom atom yang dijatuhkan di kota Hirosima dan Nagasaki yang bangkit dengan menata kembali pembangunan utama sektor bidang pendidikan untuk meningkatkan kualitas sumber daya manusia (SDM) sehingga sekarang Jepang menjadi negara yang sangat maju walaupun tidak didukung oleh sumber daya alam (SDA).

Proses perbaikan mutu pembelajaran di sekolah dilakukan secara berkelanjutan. Bahkan dalam sektor pendidikan pemerintah menganggarkan $20 \%$ dari APBN untuk mensukseskan pendidikan Nasional dan membangun SDM yang berkualitas. Adapun berbagai inovasi dan program pendidikan yang telah dilaksanakan antara lain : penyempurnaan kurikulum, pengadaan buku ajar dan buku referensi melalui berbagai pelatihan, meningkatkan kualifikasi pendidik dan tenaga kependidikan, peningkatan manajemen pendidikan, dan pengadaan berbagai fasilitas pendidikan lainnya (Depdiknas, 2003).

Masalah pendidikan dan pengajaran merupakan masalah yang cukup kompleks dimana banyak faktor yang ikut mempengaruhinya. Salah satu faktor tersebut diantaranya adalah pendidik. Pendidik merupakan komponen pengajaran yang memegang peranan penting dan utama, karena keberhasilan proses belajar mengajar sangat ditentukan oleh faktor tersebut. Tugas pendidik adalah menyampaikan materi pelajaran kepada siswa melalui interaksi komunikasi dalam proses belajar mengajar yang dilakukannya. Mengingat pentingnya pelajaran matematika pada sekolah dasar maka diperlukan pembenahan proses pembelajaran yang dilakukan guru yaitu dengan menggunakan suatu pendekatan pembelajaran yang dapat meningkatkan pemahaman siswa dalam belajar sehingga mendapatkan hasil belajar yang lebih baik. Pemilihan pendekatan pembelajaran dalam kegiatan pembelajaran yang tepat akan membuat peserta didik tertarik pada pelajaran tersebut dan tugas guru dalam menyampaikan materi akan lebih mudah dipahami dan tujuan pembelajaran 
dapat dicapai secara optimal (Riyanto, 2010).

Salah satu komponen yang mendukung proses pembelajaran adalah pendekatan pembelajaran.Menurut Komalasari (2013: 54) pendekatan pembelajaran diartikan sebagai sudut pandang terhadap proses pembelajaran, yang merujuk pada pandangan tentang terjadinya suatu proses yang sifatnya masih sangat umum yang di dalamnya mewadahi, menginspirasi, menguatkan, dan melatari metode pembelajaran dengan cakupan teoritis tertentu. Pada penelitian ini tertarik menggunakan pendekatan saintifik dikarenakan berdasarkan observasi peneliti yang dilaksanakan di MIN Tanjung Kemuning telah menggunakan kurikulum 2013.Pembelajaran dalam kurikulum 2013 inilah yang menggunakan pendekatan saintifik, tetapi pendekatan tersebut belum diterapkan secara maksimal di lembaga-lembaga madrasah/sekolah.

Berdasarkan latar belakang masalah di atas maka penelitian ini bertujuan untuk mengetahui pengaruh pendekatan saintifik terhadap hasil belajar siswa melalui pembelajaran tematik-integratif pada mata pelajaran matematika di madrasah ibtidaiyah negeri.

\section{METODE/EKSPERIMEN}

Penelitian ini menggunakan pendekatan kuantitatif dengan metode quasi-eksperimen tepatnya desain nonequivalent groups pretest-posttest. Penelitian ini melibatkan dua kelas yaitu kelas eksperimen dan kelas kontrol.Peserta didik pada kedua kelas tersebut diupayakan memiliki kemampuan yang setara.Masing-masing kelas mendapatkan perlakukan berbeda dalam proses pembelajaran, tetapi materi yang sama. Pada kelas eksperimen diberikan pembelajaran tematik integratif dengan pendekatan saintifik, sedangkan kelas kontrol diberikan pembelajaran tematik-integratif. Rancangan penelitian disajikan pada tabel $\mathrm{X}$ berikut:

Tabel 3.1

Desain Penelitian

\begin{tabular}{|l|c|c|c|}
\hline Kelompok & Pretest & Perlakua & \multicolumn{2}{|c|}{ Postt } \\
\hline Eksperimen & $\mathrm{O}_{\mathrm{a} 1}$ & $\mathrm{X}_{1}$ & $\mathrm{O}_{\mathrm{a} 2}$ \\
\hline Kontrol & $\mathrm{O}_{\mathrm{b} 1}$ & $\mathrm{X}_{2}$ & $\mathrm{O}_{\mathrm{b} 2}$ \\
\hline
\end{tabular}

Keterangan:

$\mathrm{O}_{\mathrm{a} 1}=$ Pretest pada kelas eksperimen

$\mathrm{O}_{\mathrm{b} 1}=$ Pretest pada kelas kontrol

$\mathrm{O}_{\mathrm{a} 2}=$ Posttest pada kelas eksperimen

$\mathrm{O}_{\mathrm{b} 2}=$ Posttest pada kelas kontrol

$\mathrm{X}_{1}=$ Perlakuan pembelajaran tematik-integratif dengan pendekatan saintifik

$\mathrm{X}_{2}=$ Perlakuan pembelajaran tematik-integrati

Penelitian ini menggunakan dua variabel yaitu variabel bebas dan variabel terikat. Variabel bebas sering disebut stimulus atau prediktor, yaitu variabel yang mempengaruhi atau yang menjadi sebab perubahannya atau timbulnya variabel yang dependen (terikat).Variabel bebas dalam penelitian ini adalah pembelajaran tematik-integratif dengan pendekatan saintifik. Variabel terikat sering disebut vaiabel output, kriteria, atau konsekuen, yaitu variabel yang dipengaruhi atau yang menjadi akibat dari variabel bebas. Variabel terikat dalam penelitian ini adalah hasil belajar siswa.

Populasi adalah keseluruhan gejala atau satuan yang ingin diteliti.Maka populasi dalam penelitian ini yaitu seluruh siswa dan siswi kelas IV dengan jumlah 39 orang, dapat dilihat tabel dibawah ini.

Tabel 3.2

Populasi Penelitian

\begin{tabular}{|l|c|c|cc|c|}
\hline & Kelas & \multicolumn{2}{|c|}{ Laki- } & Perempu & Jumla \\
\hline & & Laki & an & \\
\hline & IV. A & 14 & \multicolumn{2}{|c|}{9} & 23 \\
\hline
\end{tabular}




\begin{tabular}{|c|c|c|c|c|}
\hline & IV. B & 14 & 8 & 22 \\
\hline \multicolumn{2}{|l|}{ TOTAL } & & & 45 \\
\hline
\end{tabular}

Sumber: TU MIN Tanjung Kemuning

Sampel dalam Penelitian ini diambil menggunakan Sampling jenuh,sampling jenuh adalah mengambil seluruh anggota populasi sebagai sampel.untuk menentukan kelas eksperimen dan kelas kontrol, kelas eksperimen adalah kelas yang diberi perlakuan sedangkan kelas kontrol adalah kelas yang tidak diberikan perlakuan(Sugiyono, 2008)

Sampel dalam populasi ini adalah 38 orang. Menurut Suharsimi Arikunto jika subjeknya kurang dari 100 lebih baik di ambil semua, dan jika subjeknya lebih dari 100 maka sampelnya diambil antara $10 \%$ - 15\% atau $20 \%-25 \%$ atau lebih (Arikunto, 2010).

.Jumlah sampel penelitian sebagai berikut:

\section{Sampel Penelitian}

\begin{tabular}{|l|c|c|c|}
\hline o & Kelompok & Kelas & Jumlah Siswa \\
\hline$\cdot$ & Kontrol & IV.A & 23 \\
\hline & Eksperimen & IV.B & 22 \\
\hline & Jumlah & 45 \\
\hline \multicolumn{2}{|c|}{} \\
\hline
\end{tabular}

Pengumpulan data yang dilakukan dalam penelitian ini adalah dengan menggunakan tes teknik ini digunakan untuk mendapatkan informasi tentang hasil belajar siswa dengan cara memberikan serangkaian soal pretest dan posttest kepada peserta didik kelas IV di MIN Tanjung Kemuning. Teknik Observasi merupakan suatu pengamatan langsung terhadap siswa. Observasi atau pengamatan sebagai alat penilaian banyak digunakan untuk mengukur tingkah laku individu ataupun proses terjadinya suatu kegiatan yang dapat diamati, baik dalam situasi yang sebenarnya maupun dalam situasi buatan. Adapun teknik observasi yang akan digunakan dalam penelitian ini untuk mengetahui keadaan objek secara langsung serta proses pembelajaran yang berlangsung.

Data dalam penelitian ini diperoleh secara kuantitatif dari hasil tes belajar siswa.Untuk menentukan tingkat hasil belajar peserta didik, data dianalisis dengan menggunakan statistik deskriptif kuantitatif.Data yang diperoleh berupa skor pretest dan posttest yang diinterpretasi melalui pembuatan kriteria.Kategori hasil pengukuran menggunakan distribusi normal, dan untuk skala rentang (rating scale) dengan ketentuan di bawah ini.

\section{Tabel 4.}

Kategorisasi Hasil Belajar Peserta Didik

\begin{tabular}{|l|c|l|}
\hline o & Skor Peserta Didik & Kategori Karakter \\
\hline & $X \geq \bar{X}+1 . S B_{x}$ & Sangat Tinggi \\
\hline & $\bar{X}+1 . S B_{x}>X \geq \bar{X}$ & Tinggi \\
\hline & $\bar{X}>X \geq \bar{X}-1 . S B_{x}$ & Rendah \\
\hline & $X<\bar{X}-1 . S B_{x}$ & Sangat Rendah \\
\hline
\end{tabular}

Keterangan:

$\bar{X}=$ Rerata skor keseluruhan peserta didik dalam satu kelas

$S B_{x} \quad=$ Simpangan baku skor keseluruhan peserta didik dalam satu kelas

$X=$ Skor yang dicapai peserta didik

(Mardapi, 2008: 123).

Pengujian hipotesis menggunakan uji t dua sampel dengan bantuan SPSS. Taraf signifikansi $(\alpha)$ yang 
digunakan sebesar 0,05 dan kriteria keputusan yang digunakan adalah Ho ditolak jika $p$-value atau nilai signifikansi yang diperoleh kurang dari 0,05.

Hasil

\section{HASIL DAN PEMBAHASAN}

Hasil belajar peserta didik dilihat dari hasil perolehan nilai setelah dilakukan tes awal (pre-test) dan tes akhir (post-test). Dalam penelitian ini, data yang diperoleh dari hasil pre-test dan post-test akan memberikan gambaran mengenai pengaruh pendekatan saintifik terhadap hasil belajar siswaSD kelas IV melalui pembelajaran tematik-integratif pada mata pelajaran matematika.

Data pre-test memberikan gambaran hasil belajar siswa sebelum memperoleh perlakuan pendekatan saintifik. Sedangkan data post-test memberikan gambaran hasil belajar siswa setelah memperoleh perlakuan pendekatan saintifik. Deskripsi data hasil pre-test kelas kontrol dan eksperimen diperlihatkan pada tabel 4.1 berikut:

Tabel 4.1

Mean, Median, Mode, Standard Deviation Hasil Belajar Sebelum dan Sesudah Perlakuan pada Kelas Kontrol dan Kelas Eksperimen

\begin{tabular}{|c|c|c|c|c|}
\hline \multirow{2}{*}{ ripsi ${ }^{\text {Desk }}$} & \multicolumn{2}{|c|}{ Pre-test } & \multicolumn{2}{|c|}{ Post-test } \\
\hline & $\begin{array}{l}\text { Kelas } \\
\text { Kontrol }\end{array}$ & $\begin{array}{r}\text { Kelas } \\
\text { Eksperimen }\end{array}$ & $\begin{array}{l}\text { Kelas } \\
\text { Kontrol }\end{array}$ & $\begin{array}{r}\text { Kelas } \\
\text { Eksperimen }\end{array}$ \\
\hline${ }_{n} \quad$ Mea & 15,52 & 15,82 & 17,30 & 19,73 \\
\hline an & 16 & 16 & 17 & 19,5 \\
\hline$e^{\text {Mod }}$ & 16 & 16 & 19 & 19 \\
\hline $\begin{array}{l}\text { Stan } \\
\text { dard } \\
\text { Deviation }\end{array}$ & 2,01 & 2,11 & 2,14 & 1,80 \\
\hline mum $^{\text {Mini }}$ & 11 & 12 & 13 & 17 \\
\hline mum & 19 & 19 & 21 & 23 \\
\hline $\mathrm{N}$ & 23 & 22 & 23 & 22 \\
\hline
\end{tabular}

Tabel 4.1 di atas menunjukkan bahwa rata-rata nilai pre-test kelas kontrol sebesar 15,52 dan kelas eksperimen 15,82 jadi selisih 0,30. Nilai pre-test kelas kontrol berada antara nilai 10 dan 20 dengan standar deviasi 2,01 sedangkan nilai pre-test kelas eksperimen berada antara nilai 11 dan 20 dengan standar deviasi 2,11 . Selanjutnya untuk rata-rata nilai post-test kelas kontrol sebesar 17,30 dan kelas eksperimen 19,73 jadi selisih 2,43. Nilai post-test kelas kontrol berada antara nilai 14 dan 22 dengan standar deviasi 2,14 sedangkan nilai post-test kelas eksperimen berada antara nilai 18 dan 24 dengan standar deviasi 1,80.

Uji Normalitas tabel di bawah ini menyajikan data hasil uji normalitas pada hasil pre-test dan post-test siswa kelas kontrol dan kelas eksperimen dengan menggunakan uji normalitas satu sampel KolmogorovSmirnov dengan bantuan SPSS.Perumusan hipotesis yang digunakan pada uji normalitas data pada penelitian ini adalah sebagai berikut.

$\mathrm{H}_{\mathbf{0}}$ : data yang akan diuji berasal dari populasi yang berdistribusi normal.

$\mathrm{H}_{\mathrm{a}}$ : data yang akan diuji tidak berasal dari populasi yang berdistribusi normal.

Tabel 4.2 


\section{Hasil Uji Normalitas dengan Kolmogorov-Smirnov}

\begin{tabular}{|c|c|c|c|c|}
\hline Kelas & Skor & ${ }_{\text {kansi }}^{\text {Signifi }}$ & $\alpha$ & Hasil \\
\hline \multirow[b]{2}{*}{ I } & ${ }_{\text {test }}{ }^{\text {Pre- }}$ & 0,303 & 0,05 & Norma \\
\hline & $\begin{array}{ll} & \text { Post- } \\
\text { test } & \end{array}$ & 0,466 & 0,05 & Norma \\
\hline \multirow{2}{*}{ imen } & $\begin{array}{ll} & \text { Pre- } \\
\text { test } & \end{array}$ & 0,543 & 0,05 & Norma \\
\hline & $\begin{array}{ll} & \text { Post- } \\
\text { test } & \end{array}$ & 0,654 & 0,05 & Norma \\
\hline
\end{tabular}

Berdasarkan hasil uji normalitas dengan menggunakan uji normalitas satu sampel kolmogorov-Smirnov dengan bantuan SPSS tersebut didapatkan bahwa semua data yang diperoleh dari penelitian ini memiliki significant value Kolmogorov-Smirnov lebih dari 0,05 sehingga $\mathrm{H}_{0}$ diterima. Dengan demikian dapat disimpulkan bahwa data yang diuji berasal dari populasi yang berdistribusi normal. Output dari uji normalitas dengan menggunakan uji normalitas satu sampel kolmogorov-Smirnov dengan bantuan SPSS untuk data yang diperoleh pada penelitian ini dapat dilihat pada lampiran.

Uji Homogenitas Tabel di bawah ini menyajikan data hasil uji homogenitas pada hasil pre-test dan posttest siswa menggunakan uji homogenity of variance dengan bantuan SPSS dan interpretasi dilakukan dengan statistik yang didasarkan pada rata-rata (based on mean).Perumusan hipotesis yang digunakan pada uji homogenitas data pada penelitian ini adalah sebagai berikut.

$\mathrm{H}_{0}$ : variansi kedua populasi (darimana kelompok eksperimen dan kontrol diambil) sama besar.

$\mathrm{H}_{\mathrm{a}}$ : variansi kedua populasi (darimana kelompok eksperimen dan kontrol diambil) tidak sama besar.

Tabel 4.3

\section{Hasil Uji Homogenitas}

\begin{tabular}{|c|c|c|c|c|}
\hline 0 & Data & kansi & $\alpha$ & Hasil \\
\hline & $\begin{array}{ll} & \text { Pre- } \\
\text { test } & \end{array}$ & 0,692 & 0,05 & gen Homo \\
\hline & test ${ }^{\text {Post- }}$ & 0,287 & 0,05 & gen Homo \\
\hline
\end{tabular}

Berdasarkan hasil uji homogenitas menggunakan uji homogenity of variance dengan bantuan SPSS, didapatkan bahwa significant value pada hasil pre-test dan post-test siswa lebih dari 0,05 sehingga $\mathrm{H}_{0}$ diterima. Dengan demikian dapat disimpulkan bahwa variansi kedua populasi (darimana kelompok eksperimen dan kontrol diambil) sama besar (homogen). Output dari uji homogenitas menggunakan uji homogenity of variance dengan bantuan SPSS untuk data yang diperoleh pada penelitian ini dapat dilihat pada lampiran.

Pengujian hipotesis penelitian bertujuan untuk mengetahui apakah terdapat pengaruh pendekatan saintifik terhadap hasil belajar peserta didik melalui pembelajaran tematik-integratif. Berdasarkan hasil pengujian dengan independent sample $t$-test dengan bantuan SPSS dan taraf signifikansi $\alpha=0,05$, didapatkan nilai signifikansi sebesar 0,000 . Dengan demikian maka nilai signifikansi yang didapatkan kurang dari 0,05 sehingga $\mathrm{H}_{0}$ ditolak.

\section{PENUTUP}

Berdasarkan hasil penelitian dan hasil analisis data yang telah dilakukan, dapat disimpulkan, pembelajaran tematik-integratif dengan pendekatan saintifik berpengaruh positif terhadap hasil belajar siswa, 
Pembelajaran tematik-integratif dengan pendekatan saintifik memberikan pengaruh yang lebih baik terhadap hasil belajar siswa, dalam arti bahwa hasil belajar siswa dengan menggunaka pendekatan saintifik lebih besar dibandingkan dengan menggunakan pendekatan biasa (konvensional).

Penelitian ini bertujuan untuk menguji pengaruh pendekatan saintifik terhadap hasil belajar peserta didik melalui pembelajaran tematik-integratif.Berdasarkan pengujian untuk rumusan masalah, diperoleh bahwa terdapat pengaruh pendekatan saintifik terhadap hasil belajar peserta didik melalui pembelajaran tematik-integratif. Penelitian ini dapat menunjukkan bahwa pembelajaran yang menggunakan pendekatan saintifik menghasilkan peningkatan hasil belajar yang lebih tinggi jika dibandingkan dengan menggunakan pembelajaran konvensional.Dengan adanya pembelajaran tematik-integratif dengan pendekatan saintifik dapat dijadikan acuan oleh guru dalam menyampaikan materi. Sehingga siswa tidak menjadi pasif dan hanya medengarkan materi yang diajarkan, tetapi juga berperan aktif dalam proses pembelajaran.

\section{UCAPAN TERIMAKASIH}

Terimakasih kepada Ketua STKIP Nurul Huda OKUT, Ketua LPPM STKIP Nurul Huda OKUT, Anggota Jurnal Jemari STKIP Nurul Huda OKUT, Kepala SD N Ulak Buntar beserta jajarannya, Dan Dosen-Dosen STKIP Nurul Huda OKUT.

\section{DAFTAR PUSTAKA}

Budiyanto, M. A. K., Waluyo, L., \& Mokhtar, A. (2016).Implementasi pendekatan saintifik dalam pembelajaran di pendidikan dasar di Malang.Proceeding Biology Education Conference, 13 (1), 46 - 51.

Capay, M. \& Magdin, M. (2013). Tasks for teaching scientific approach using the black box method. Academic Conferences and Publishing International Limited.Diambil pada tanggal 20 Juli 2018, dari https://www.researchgate.net.

Hajar, I. (2013). Panduan lengkap kurikulum tematik untuk SD/MI. Yogyakarta: Diva Press.

Hamalik, O. (2007). Proses belajar mengajar. Jakarta: Bumi Aksara.

Helmiati.(2012). Model pembelajaran.Yogyakarta: Aswaja Pressindo.

Hosnan, M. (2014).Pendekatan saintifik dan kontekstual dalam pembelajaran abad 21 kunci sukses implementasi kurikulum 2013.Bogor: Ghalia Indonesia.

Jihad, A., \& Haris, A. (2010). Evaluasi pembelajaran.Yogayakrta: Multi Pressindo.

Kemendikbud.(2013). Lampiran IV Peraturan Menteri Pendidikan dan Kebudayaan Nomor 81A Tahun 2013 Tentang Implementasi Kurikulum Pedoman Umum Pembelajaran.

Komalasari, K. (2013). Pembelajaran kontekstual dan aplikasi.Bandung: Refika Aditama.

Majid, A. (2014). Pembelajaran tematik terpadu.Bandung: PT Remaja Rosdakarya.

Mednick, F. (2006) Instructional theories. Connection module.Diambil pada tanggal 20 Juli 2018 dari http://enx.org/content/m13291/1.5/

Michael, R. S. (2002). Strategies for educational inquiry: inquiry and scientific methods. Fall 2002-Y520: 5982, page 3

Miller, M. D., Linn, R. L., \& Gronlund, N. E. (2009). Measurement and Assesment in Teaching. New Jersey: Pearson Education.

Musfiqon, H. M., \& Nurdyansyah.(2015). Pendekatan pembelajaran saintifik.Sidoarjo: Nizamia Learning Center.

Nitko, A. J., \& Brookhart, S. M. (2011). Educational asessment of students( $6^{\text {th }}$ ed). Boston: Pearson Education.

Nurdyansyah \& Fahyuni, E. F. (2016). Inovasi model pembelajaran sesuai kurikulum 2013. Sidoarjo: Nizamia Learning Center

Riyanto. 2010. Strategi belajar mengajar. Bandung: Pustaka setia

Rusman.(2012). Model-model pembelajaran.Bandung: Rajawali Pers.

Santrock, J. W. (2011). Educational psychology ( $5^{\text {th }}$ ed). New York: McGraw-Hill Companies. 
70 | Jemari: Jurnal Edukasi Madrasah Ibtidaiyah, Vol. 1 No. 2,Halaman: 64 - 70, Juli, 2019

Slameto.(2010). Belajar dan faktor-faktor yang mempengaruhinya.Jakarta: Rineka Cipta.

Sudjana, N. (2009). Dasar-dasar proses belajar mengajar. Bandung: Sinar Baru Algesindo.

Sukmadinata, N. S. (2009). Landasan psikologi proses pendidikan. Bandung: PT Remaja Rosdakarya. 